\title{
On the biology of two high mountain populations of stoneflies (Plecoptera, Perlodidae) in the southern Iberian Peninsula
}

\author{
Manuel Jesús López-Rodríguez ${ }^{1,4, *}$, Julio Miguel Luzón-Ortega ${ }^{2}$ and José Manuel Tierno de \\ Figueroa ${ }^{3,4}$
}

${ }^{1}$ Departamento de Ecología, Facultad de Ciencias, Universidad de Granada, Campus Fuentenueva s/n, 18071, Granada, Spain.

${ }^{2}$ Hydraena S.L.L. Plaza del Baño, 4. 18170 Alfacar, Granada, Spain.

${ }^{3}$ Departamento de Zoología, Facultad de Ciencias, Universidad de Granada, Campus Fuentenueva s/n, 18071, Granada, Spain.

${ }^{4}$ Instituto del Agua. Universidad de Granada. 18071, Granada, Spain.

* Corresponding author: manujlr@ugr.es

Received: 20/6/11 Accepted: 27/12/11

\begin{abstract}
On the biology of two high mountain populations of stoneflies (Plecoptera, Perlodidae) in the southern Iberian Peninsula

The life history of two species of Perlodidae stoneflies, Perlodes microcephalus (Pictet, 1833) and Isoperla nevada Aubert, 1952, are studied in a high mountain stream of the Sierra Nevada (Granada, Spain). Both species show a univoltine life cycle. The nymphal development of $P$. microcephalus occurs mainly in summer and autumn, and adults emerge at the end of spring. The embryonic development period is short, taking only two months. I. nevada develops and grows mainly during the summer, but the embryonic development period is even shorter. Despite both species having a relatively similar nymphal development period, $P$. microcephalus reaches a considerably larger size than I. nevada. The two taxa behave as predators, but $P$. microcephalus exhibits a wider prey spectrum. Thus, although $I$. nevada is more abundant in the studied stream, $P$. microcephalus appears to play a more important role as top predator.
\end{abstract}

Key words: Perlodes microcephalus, Isoperla nevada, life cycle, nymphal feeding, Sierra Nevada, Spain.

\section{RESUMEN}

Sobre la biología de dos poblaciones de plecópteros de alta montaña (Plecoptera, Perlodidae) en el sur de la Península Ibérica

Se estudian las estrategias vitales de dos especies de plecópteros Perlodidae, Perlodes microcephalus (Pictet, 1833) e Isoperla nevada Aubert, 1952, en un arroyo de alta montaña de Sierra Nevada (Granada, España). Ambas muestran un ciclo de vida univoltino. El desarrollo de las ninfas de P. microcephalus tiene lugar principalmente en verano y otoño, y los adultos emergen al final de la primavera. El período de desarrollo embrionario es corto, de solo dos meses. También I. nevada se desarrolla y crece principalmente durante el verano, pero el período de desarrollo embrionario es incluso más corto. A pesar de que ambas especies tienen un período de desarrollo de las ninfas relativamente similar, P. microcephalus alcanza un tamaño considerablemente mayor que I. nevada. Los dos taxones se comportan como depredadores, pero P. microcephalus exhibe un espectro de presas más amplio. Así pues, a pesar de que I. nevada es más abundante en el arroyo estudiado, P. microcephalus parece jugar un papel más importante como depredador en esta comunidad fluvial.

Palabras clave: Perlodes microcephalus, Isoperla nevada, ciclo de vida, alimentación de las ninfas, Sierra Nevada, España. 


\section{INTRODUCTION}

High mountain streams are systems with particular characteristics, such as low water temperature (generally lower than $10^{\circ} \mathrm{C}$, even in the summer), fast flow, high turbulence and oxygen content, and an almost complete absence of plankton and macrophytes (Stoch, 2008). These pressures favour the development of particular strategies to cope with low temperatures and the relative scarcity of resources, mainly in those streams above the tree line. Some aquatic insects find in these environments an "island" of proper conditions to grow and are closely linked to these ecosystems. This is the case of some stoneflies, whose temperature optimum is low compared with other aquatic insects. In our study, we focus on two species of Plecoptera that inhabit a high mountain stream in the Sierra Nevada (Granada, Spain): Perlodes microcephalus (Pictet, 1833) and Isoperla nevada Aubert, 1952.

Perlodes microcephalus is a widely distributed species in a large part of Europe (Fochetti \& Tierno de Figueroa, 2004). Nevertheless, its presence in the southern Iberian Peninsula is highly punctual and is reduced to few populations in the high mountains of the Sierra Nevada (Southern Spain) (Tierno de Figueroa et al., 2003). In more meridional mountains, such as the Pyrenees, this species is found at lower altitudes (300-1400 m.a.s.l.) than the congeneric $P$. intricatus (1000-2200 m.a.s.l.), which replaces $P$. microcephalus at higher altitudes (Berthélemy, 1966). In fact, the population in Sierra Nevada is one of the highest-altitude populations of P. microcephalus in Europe. For stoneflies, these mountains act more as a refuge for northern species, such as $P$. microcephalus, than as a speciation centre (Tierno \& Sánchez-Ortega, 1996).

In contrast, I. nevada Aubert, 1952, is endemic to the Iberian Peninsula and is widely distributed within it, with an altitudinal range of 800 to 2900 m.a.s.l. (Tierno de Figueroa et al., 2003).

The aim of this work is to deepen the understanding of the biology of these species under low-temperature conditions by studying their life cycle and nymphal feeding and to compare these results with those previously reported in nearby areas and in other parts of Europe.

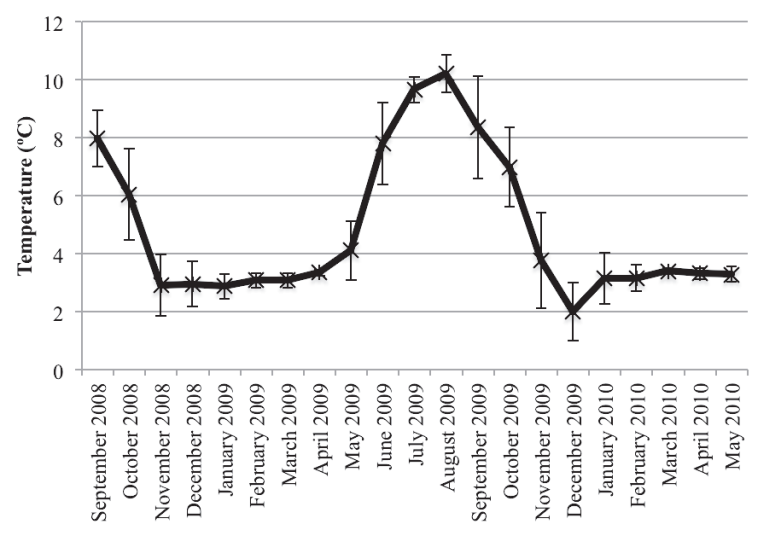

Figure 1. Mean daily temperature recorded during the study period. Temperatura media diaria registrada durante el período de estudio.

\section{MATERIAL AND METHODS}

The study was performed in the Puerto de Jeres stream (Sierra Nevada, Granada, Spain. 30S X: 479419, Y: 4104892) at 2500 m.a.s.l. Samplings were performed at monthly intervals over two years (from June 2008 to May 2010) except for some winter months, when snow made it impossible to reach the sampling site. In fact, the stream was covered with snow for 6 months during the first year of study and for 5 months during the second. Nymphs were collected with a Surber sampler $\left(0.16 \mathrm{~m}^{2}\right.$ and $250 \mu \mathrm{m}$ mesh size) and preserved in $4 \%$ formalin. Six Surbers were collected on each date. Because these samples provided few nymphs, other samples were captured using a kick net $(250 \mu \mathrm{m}$ mesh size). Nymphs from both samples were used to represent the life cycle and to study feeding, but only nymphs from the Surber sampler were used to estimate the densities. At the same time, some physicochemical parameters were recorded (Table 1). Temperature was recorded hourly with a HOBO ${ }^{\circledR}$ U22 Water Temp Pro V2 Data Logger (Fig. 1). Adults were searched for in the stones of both shores and in the riparian vegetation. Adult collection was conducted with tweezers, and the material was preserved in $70 \%$ ethanol. The total length of the nymphs of both species was measured under a stereomicroscope with an ocular micrometre. The nymphs were grouped 
Table 1. Mean \pm SD of the physicochemical parameters in the study site for each year. Media \pm DS de parámetros físicos medidos en el punto de muestreo para cada año.

\begin{tabular}{|c|c|c|c|c|c|c|c|c|c|}
\hline \multicolumn{2}{|c|}{ Discharge (1/s) } & \multicolumn{2}{|c|}{$\mathrm{pH}$} & \multicolumn{2}{|c|}{ Conductivity $(\mu \mathrm{S} / \mathrm{cm})$} & \multicolumn{2}{|c|}{$\% \mathrm{O}_{2}$} & \multicolumn{2}{|c|}{$\mathrm{O}_{2}(\mathrm{mg} / \mathrm{l})$} \\
\hline $1^{\text {st }}$ & $2^{\text {nd }}$ & $1^{\text {st }}$ & $2^{\text {nd }}$ & $1^{\mathrm{st}}$ & $2^{\text {nd }}$ & $1^{\text {st }}$ & $2^{\text {nd }}$ & $1^{\text {st }}$ & $2^{\text {nd }}$ \\
\hline $114.6 \pm 101.5$ & $138.5 \pm 109.5$ & $7.3 \pm 0.2$ & $7.7 \pm 0.7$ & $14.0 \pm 1.4$ & $17.8 \pm 4.2$ & $83.9 \pm 11.4$ & $85.1 \pm 11.0$ & $8.0 \pm 0.5$ & $9.1 \pm 1.2$ \\
\hline
\end{tabular}

into intervals to represent the life cycle using FiSAT II software (Gayanilo et al., 2002). Although no data were available for some months, nymphal development and growth were inferred for these months, as in Silveri et al. (2008).

Some of the P. microcephalus nymphs (the largest) were dissected $(N=12)$, while others (the smallest) were clarified $(N=24)$ with Hertwigs' liquid to study their gut content, as in other studies on nymphal feeding (e.g., LópezRodríguez et al., 2009). All the studied nymphs of I. nevada were clarified $(N=54)$ using this method. Only the presence of each nonanimal component of the diet was considered, without analysing its abundance.

\section{RESULTS}

Due to the adverse conditions of this high mountain environment, but mainly because of the scarcity of this relict species in the area, only 59 nymphs of $P$. microcephalus were collected during the two years (18 in the first and 41 in the second). However, these nymphs provide a clear representation of the life cycle of $P$. microcephalus, particularly in the second year. Despite an intensive search, only one adult (a male) of this species was captured in June 2009. However, a total of 187 nymphs (73 the first year and 114 the second) and 21 adults (9 the first year and 12 the second) of I. nevada were collected at the sampling site.

The life cycle of $P$. microcephalus was univoltine at the study site, with nymphs hatching at the end of July (after approximately two months of embryonic development) and mature nymphs present at the end of May (Fig. 2). Although only one adult was collected, its flight period is probably short, approximately one month, because no nymphs are present in the stream after May. Nymphal growth is rapid from July to the end of November. Although no data are available from December to April, the presence of nymphs of the same size before and after this period in the second year suggests that little or no growth occurs during these colder months, although in the first year, nymphal growth seems to occur. The only adult collected the first year was found in June.

I. nevada has a univoltine life cycle at this site (Fig. 3). The hatching of nymphs occurs mainly in August, although a longer recruitment period

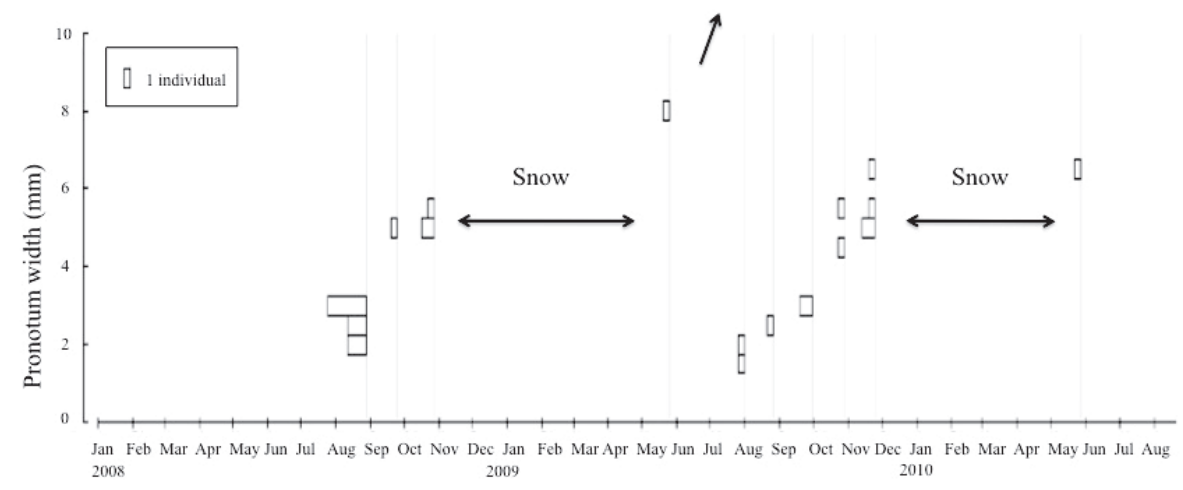

Figure 2. Size-frequency graph showing the life cycle of Perlodes microcephalus. The presence of adults on the sampling dates is marked with an arrow. Representación gráfica de la frecuencia de tamaños a lo largo del ciclo de vida de Perlodes microcephalus. Se han capturado adultos en las fechas de muestreo marcadas con una flecha. 


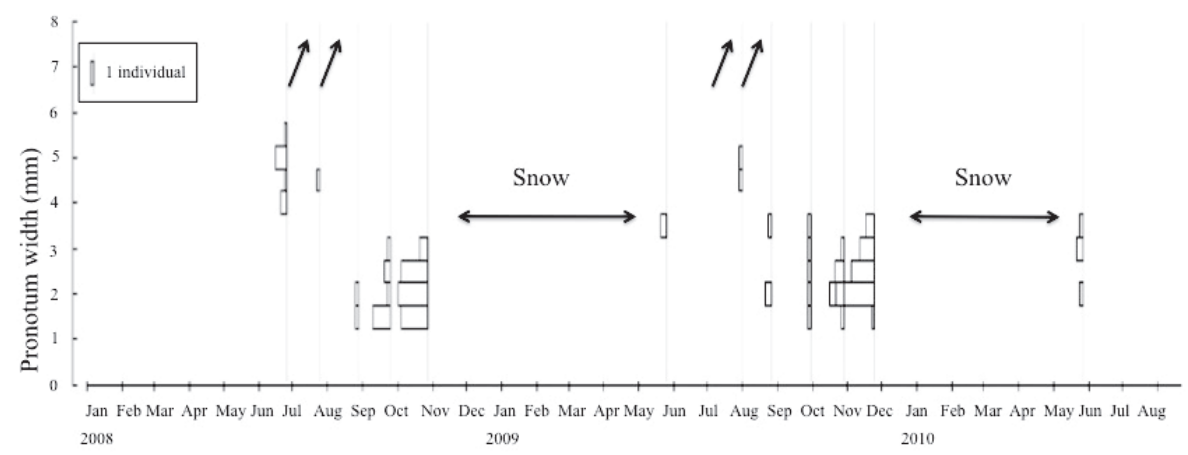

Figure 3. Size-frequency graph showing the life cycle of Isoperla nevada. The presence of adults on the sampling dates is marked with an arrow. Representación gráfica de la frecuencia de tamaños a lo largo del ciclo de vida de Isoperla nevada. Se han capturado adultos en las fechas de muestreo marcadas con una flecha.

seems to exist. Adults emerge in the summer. No data are available for the winter and spring months, but little growth seems to occur during this period because after this period, we could still find some small nymphs. The embryonic development is rapid, lasting scarcely one month. Adults were collected in June and July of the first year and in July and August of the second year.

The mean monthly density of individuals during the months when nymphs were present in the stream was $4.29 \mathrm{ind} / \mathrm{m}^{2}$ for $P$. microcephalus and $15.27 \mathrm{ind} / \mathrm{m}^{2}$ for I. nevada.

Ten of the 50 studied nymphs of $P$. microcephalus had empty guts. Of the remaining 40 , 34 contained some animal matter $(85.0 \%)$ and only six had ingested exclusively non-animal matter. The diet study showed that the nymphs fed mainly on Diptera Chironomidae $(75.0 \%$ of the nymphs), but also on Ephemeroptera Baetidae $(7.5 \%)$, Plecoptera Nemouroidea $(2.5 \%)$, Trichoptera Hydropsychidae (2.5\%), Glossosomatidae $(2.5 \%)$, and Nematomorpha $(2.5 \%)$ (Table 2). The $5 \%$ of the gut contents studied included unidentifiable Trichoptera larvae and Ephemeroptera nymphs. Some nymphs ingested detritus, algae (mainly diatoms), coarse particulate organic matter (CPOM), hyphae and pollen (Table 2). Sand grains were found in four nymphs.

The gut contents of $54 \mathrm{I}$. nevada nymphs were analysed. Twenty-six nymphs had empty guts. The remaining 28 had eaten some animal prey, though many of them also contained detritus $(21.4 \%)$, algae $(14.3 \%)$ and sand grains
(7.1\%). Diptera Chironomidae was the prey this species ingested most, although unidentifiable Plecoptera and Ephemeroptera were also consumed by this species (Table 2).

Regarding number of prey found in the gut of each species, the nymphs of $P$. microcephalus

Table 2. Presence of different food items in the gut contents of the studied species. $N=$ the number of individuals that contain a food item; $\%=$ the percentage of individuals that fed on each food item with respect to the total number of individuals with full guts. Tipos de alimento presentes en el contenido digestivo de las especies estudiadas. $\mathrm{N}=$ número de individuos que contienen un recurso concreto; $\%=$ porcentaje de individuos que han comido un recurso en relación al número total de individuos que tienen el digestivo lleno.

\begin{tabular}{lrrrr}
\hline & \multicolumn{2}{c}{ Perlodes } & \multicolumn{2}{c}{ Isoperla } \\
& microcephalus & \multicolumn{2}{c}{ nevada } \\
& $\mathrm{N}$ & $\%$ & $\mathrm{~N}$ & $\%$ \\
\hline Detritus & 21 & 52.5 & 6 & 21.4 \\
Sand & 4 & 10.0 & 2 & 7.1 \\
Algae & 17 & 42.5 & 4 & 14.3 \\
Hyphae & 1 & 2.5 & 0 & 0.0 \\
CPOM & 5 & 12.5 & 0 & 0.0 \\
Pollen & 1 & 2.5 & 0 & 0.0 \\
Non-identifiable animals & 4 & 10.0 & 4 & 14.3 \\
Chironomidae & 30 & 75.0 & 21 & 75.0 \\
Plecoptera undet. & 0 & 0.0 & 1 & 3.6 \\
Plecoptera Nemouroidea & 1 & 2.5 & 0 & 0.0 \\
Ephemeroptera undet. & 2 & 5.0 & 1 & 3.6 \\
Baetidae & 3 & 7.5 & 0 & 0.0 \\
Nematomorpha & 1 & 2.5 & 0 & 0.0 \\
Hydropsychidae & 1 & 2.5 & 0 & 0.0 \\
Glossosomatidae & 1 & 2.5 & 0 & 0.0 \\
Trichoptera undet. & 2 & 5.0 & 0 & 0.0 \\
\hline Ind. with gut contents & 34 & 85.0 & 26 & 92.9 \\
\hline
\end{tabular}


ingested up to 54 larvae of Chironomidae, while the maximum number of prey recorded in the nymphs of I. nevada was five Chironomidae (Fig. 4).

\section{DISCUSSION}

Studies in other European areas show a univoltine life cycle for $P$. microcephalus [e.g., in Great Britain (Hynes, 1941, 1961; Elliott, 1967, 1992, 2000) and in Fennoscandia (Lillehammer, 1988)]. Elliott (2000) in particular mentioned that this species has very rapid growth, attaining a size similar to that of large perlids in only one year, while the latter require approximately two or three years to complete their development in cold waters. The embryonic development of approximately two months in the Puerto de Jeres stream coincides with that found in several studies in similar temperatures. For example, Marten (1991) found that in experimental studies in Germany, egg development at approximately $10-11{ }^{\circ} \mathrm{C}$ (the temperature of the Puerto de Jeres stream during the months in which the eggs are present, Fig. 1) lasted 50-60 days, while Elliott (1992), in a experimental study in Great Britain, found that the maximum hatching period occurs approximately 2-2.5 months after oviposition at temperatures of approximately $11{ }^{\circ} \mathrm{C}$. These results are very similar to those previously found by Schwarz (1970) for this species, who noted an embryonic development period from 56 to 70 days depending on temperature $\left(5-16^{\circ} \mathrm{C}\right)$. Nevertheless, Berthélemy (1979) mentioned that the
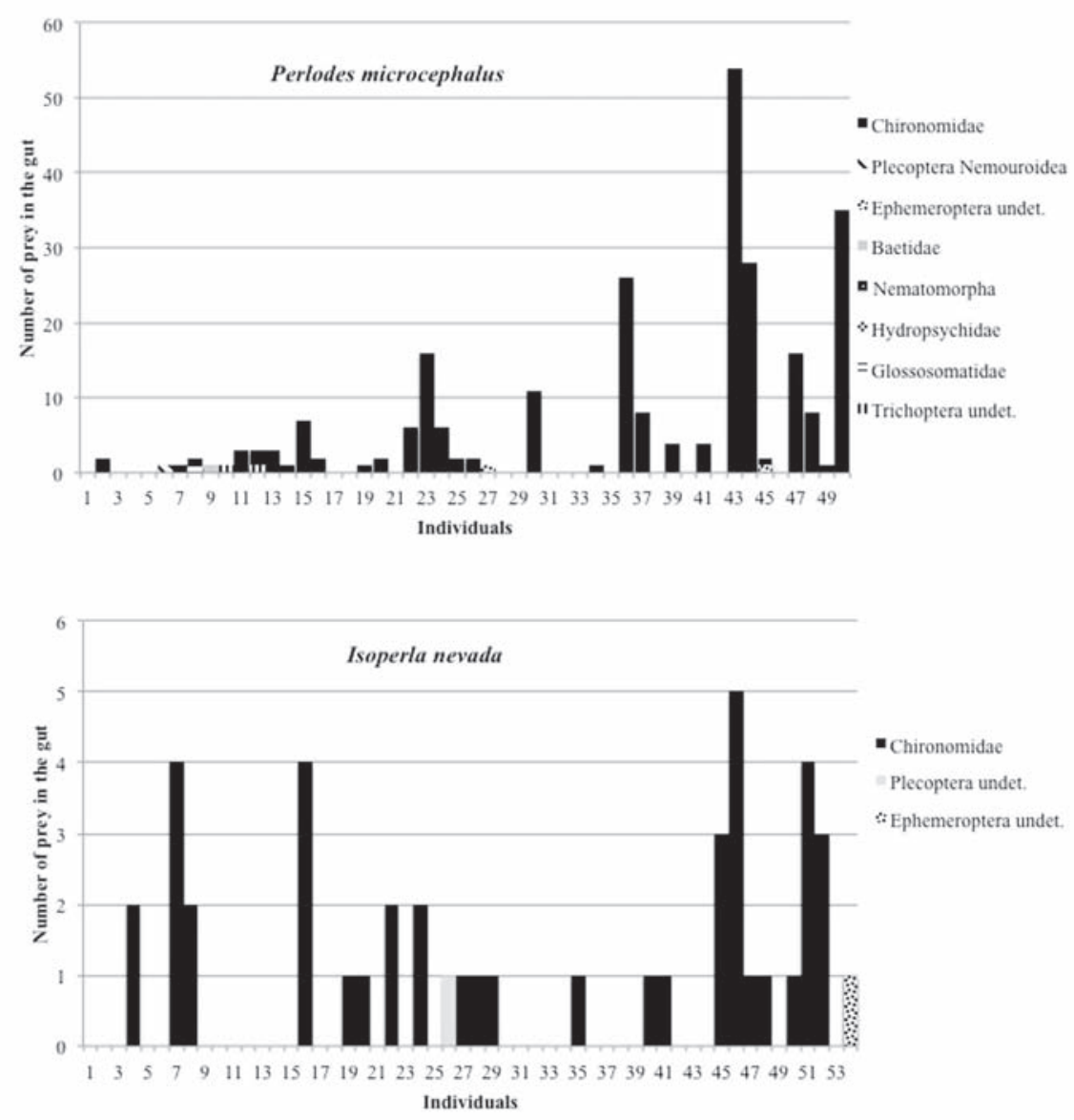

Figure 4. Number of each prey found in the gut contents of the studied nymphs. Número de individuos de cada tipo de presa encontrados en el digestivo de las ninfas estudiadas. 
eggs of this species could hatch at 2-5 months after oviposition or one year later. Under this hypothesis, which has not been confirmed by experimental data, if nymphal development occurs in approximately one year, the life cycle would be semivoltine for some individuals.

Regarding nymphal growth, Elliott (1967) noted, in a study in Great Britain, that P. microcephalus was the only species that did not slow down growth in the winter months. The data in the Puerto de Jeres stream from the second year do not seem to support this conclusion, though in the first year, some growth seems to occur.

Although only one adult was captured, the flight period can be inferred to occur in the spring, based on the presence of mature nymphs in June.

Thus, the general life cycle pattern of P. microcephalus in the southern Iberian Peninsula is very similar to that found at higher latitudes. The flight period appears to be delayed in comparison with some of these areas: Hynes (1961) cited that emergence occurs in April, and Graf et al. (2009) suggested that it occurs mainly in the spring. This period is advanced in other places, such as in the Pyrenees, where adults are collected up to August (Sánchez-Ortega et al., 2002).

Additionally, for I. nevada, a univoltine life cycle has already been noted by Sánchez-Ortega \& Alba-Tercedor (1990) in the nearby Dílar stream, Sierra Nevada [but was identified as I. grammatica (Poda, 1761), see Tierno \& Sánchez-Ortega (1994)]. In this stream, the population had a similar pattern: mature nymphs were recorded in July, and hatching began in September; they also found a short period of embryonic development.

The flight period of this species is summer, but it was slightly delayed in the second year of the study. A similar flight period has been recorded in other areas at altitudes between 1510 and 1900 m.a.s.l. (Tierno de Figueroa et al., 2001, 2003), although this period was longer at these altitudes than in the Puerto de Jeres stream, probably because of the higher altitudes. At our study site, the short time with relatively favourable conditions for the adults would have reduced the emergence and flight period.

Regarding feeding, the nymphs of both $P . m i$ crocephalus and I. nevada are clearly predators, although some of them also fed on non-animal matter and others behaved solely as detritivorousherbivorous (ingesting only detritus, algae and/or CPOM). The presence of sand grains in several nymphs is probably anecdotic and could be related to the feeding behaviour of this species, as field observations made by the authors show that nymphs ingest non-animal matter together with prey when feeding on soft substrates (e.g., mud, sand). Nonetheless, these grains could proceed from the case of ingested caddisflies, as at least in one of the nymphs, Trichoptera were found together with the sand grains.

Nymphal feeding in other streams has been studied only in P. microcephalus. Our study is in agreement with these previous studies with respect to the prey eaten. For example, Fenoglio et al. (2005) found that Chironomidae were the most frequent prey found in the gut of a northwestern Italian population of this species and that some families of Trichoptera (Glossosomatidae, for instance) were also positively selected among the entire community of potential prey. Additionally, Berthélemy \& Lahoud (1981), in a study performed in the Pyrenees, found that Chironomidae (60-85\%), followed by Baetis sp. (30\%) were the main prey consumed by this species, and they also recorded non-animal contents in the gut.

Comparing the feeding habits of P. microcephalus and $I$. nevada, it is noteworthy that the first species has a wider prey spectrum than the latter, and $P$. microcephalus ingested a quantitatively higher number of prey than $I$. nevada. Thus, despite being less abundant in the study site, $P$. microcephalus exerts greater predatory pressure and, thus, a higher control on other aquatic insects than I. nevada. This higher ingestion rate would be essential in an insect that must achieve a large size in a very short period and under very low temperatures.

\section{ACKNOWLEDGEMENTS}

The authors wish to thank to two anonymous referees for their helpful comments, which greatly improved the original version of the manuscript. This research has been supported by the Span- 
ish project "Programa de seguimiento de los efectos del cambio global en el Parque Nacional y Natural de Sierra Nevada, Consejería de Medio Ambiente, Junta de Andalucía" and by the project "CGL2008-02221" (Ministerio de Ciencia e Innovación, Spain).

\section{REFERENCES}

BERTHÉLEMY, C. 1966. Recherches écologiques et biogéographiques sur les Plécoptères et Coléoptères d'eau courante (Hydraena et Elminthidae) des Pyrénées. Annales de Limnologie, 1: 227-458.

BERTHÉLEMY, C. 1979. Accouplement, période d'incubation et premiers stades larvaires de Brachyptera braueri et de Perlodes microcephalus (Plecoptera). Annales de Limnologie, 15: 317-335.

BERTHÉLEMY, C. \& M. LAHOUD. 1981. Régimes alimentaireset pièces buccales de quelques Perlodidae et Perlidae des Pyrénées (Plecoptera). Annales de Limnologie, 17: 1-24.

ELLIOTT, J. M. 1967. The life histories and drifting of the Plecoptera and Ephemeroptera in a Dartmoor stream. Journal of Animal Ecology, 36: 243262.

ELLIOTT, J. M. 1992. The effect of temperature on egg hatching for three populations of Perlodes microcephala (Pictet) and three populations of Diura bicaudata (Limnaeus) (Plecoptera: Perlodidae). Entomologist's Gazette, 43: 115-123.

ELLIOTT, J. M. 2000. Contrasting diel activity and feeding patterns of four species of carnivorous stoneflies. Ecological Entomology, 25: 26-34.

FENOGLIO, S., T. BO \& M. CUCCO. 2005. Winter prey preference of Perlodes microcephalus (Pictet, 1833)(Plecoptera, Perlodidae) nymphs in an Apenninic creek, northwestern Italy. Entomological News, 116: 245-252.

FOCHETTI, R. \& J. M. TIERNO DE FIGUEROA. 2004. Plecoptera. Fauna Europaea Web service. www.faunaeur.org (Fauna Europaea Project Ref. EVR1-CT-1999-2001).

GAYANILO, F. C. JR., P. SPARRE \& D. PAULY. 2002. FiSAT II (ver. 1.2.0.). Food and Agriculture Organization of the United Nations (FAO) (www.fao.org/fi/statist/fisoft/fisat/index.htm).

GRAF, W., A. LORENZ, J. M. TIERNO DE FIGUEROA, S. LÜCKE, M. J. LÓPEZ-RODRÍGUEZ \& C. DAVIES. 2009. Plecoptera. In: Dis- tribution and Ecological Preferences of European Freshwater Organisms. A. Schmidt-Kloiber \& D. Hering (eds.): 207-223. Pensoft Publishers. Sofia. Bulgaria.

HYNES, H. B. N. 1941. The taxonomy and ecology of the nymphs of British Plecoptera, with notes on the adults and eggs. Transactions of the Entomological Society of London, 91: 459-557.

HYNES, H. B. N. 1961. The invertebrate fauna of a Welsh mountain stream. Archiv für Hydrobiologie, 57: 344-388.

LILLEHAMMER, A. 1988. Stoneflies (Plecoptera) of Fennoscandia and Denmark. Fauna Entomologica Scandinava. Vol. 21. E. J. Brill, Scandinavian Science Press LTD. 165 pp.

LÓPEZ-RODRÍGUEZ, M. J., J. M. TIERNO DE FIGUEROA, S. FENOGLIO, T. BO \& J. ALBATERCEDOR. 2009. Life strategies of 3 Perlodidae species (Plecoptera) in a Mediterranean seasonal stream in southern Europe. Journal of the North American Benthological Society, 28: 611-625.

MARTEN, M. 1991. The effect of temperature on the egg incubation period of $P$. microcephalus, $P$. dispar (Pl.: Perlod.) and Perla burmeisteriana (Pl.: Perlid.). In: Overview and strategies of Ephemeroptera and Plecoptera. J. Alba-Tercedor \& A. Sánchez-Ortega (eds.): 387-401. The Sandhill Crane Press. Inc. Florida. USA.

SÁNCHEZ-ORTEGA, A. \& J. ALBA-TERCEDOR. 1990. Life cycles of some species of Plecoptera in Sierra Nevada (South of Spain). In: Mayflies and Stoneflies: Life history and Biology. I. C. Campbell (ed.): 43-52. Kluwer Academic Publishers. Dordrech. Holland.

SÁNCHEZ-ORTEGA, A., J. ALBA-TERCEDOR \& J. M. TIERNO DE FIGUEROA. 2002. Lista faunística y bibliográfica de los plecópteros (Insecta, Plecoptera) de la Península Ibérica e Islas Baleares. Publicaciones de la Asociación española de Limnología. Madrid. España. 198 pp.

SCHWARZ, P. 1970. Autokologische untersuchungen zum Lebenszyklus von setipalpia-arten (Plecoptera). Archiv für Hydrobiologie, 67(1): 103-140.

SILVERI, L., J. M. TIERNO DE FIGUEROA \& B. MAIOLINI. 2008. Notes on the nymphal biology of Nemoura mortoni Ris 1902 (Plecoptera, Nemouridae) in a high altitude stream (Trentino, Italian Alps). Zoologica Baetica, 19: 51-56.

STOCH, F. 2008. Ecologia dei torrenti montani. In: Torrenti montani. La vita nelle acque correnti. F. Stoch (ed.): 101-119. Ministero dell'Ambiente e 
della Tutela del Territorio e del Mare-Museo Friulano do Storia Naturale. Udine. Italy.

TIERNO, J. M. \& A. SÁNCHEZ-ORTEGA. 1994. Sobre la distribución espacial y temporal de Isoperla nevada Aubert, 1952 (Insecta: Plecoptera). Zoologica Baetica, 5: 107-112.

TIERNO, J. M. \& A. SÁNCHEZ-ORTEGA. 1996.

Revisión de la distribución y el estado de conservación de la fauna de Plecópteros (Insecta: Plecoptera) de los sistemas montañosos andaluces, con especial referencia a S. Nevada. Proceedings of $1^{a}$ Conferencia Internacional Sierra Nevada.
Conservación y Desarrollo Sostenible, 3: 69-74. TIERNO DE FIGUEROA, J. M., J. M. LUZÓNORTEGA \& A. SÁNCHEZ-ORTEGA. 2001. Fenología de los plecópteros (Insecta, Plecoptera) de Sierra Nevada (Granada, España). Zoologica Baetica, 12: 49-70.

TIERNO DE FIGUEROA, J. M., A. SÁNCHEZ-ORTEGA, P. MEMBIELA-IGLESIA \& J. M. LUZÓN-ORTEGA. 2003. Plecoptera. In: Fauna Ibérica, vol. 22, M. A. Ramos et al. (eds.): 66-72. Museo Nacional de Ciencias Naturales. CSIC. Madrid. España. 